\title{
Clinical Features and Surgical Treatment of Aggressive Meningiomas
}

\section{Agresif Menenjïyomlarm Klinik Özellikleri ve CerrahiTedavisi}

\author{
Hongwei WANG, Shujiang NIU, Chuanwei WANG, Yuguang LIU \\ Qilu Hospital of Shandong University, Brain Science Research Institute of Shandong University, Department of Neurosurgery, Jinan, PR China
} Corresponding Author: Yuguang LIU / E-mail: NS3000@126.com

\begin{abstract}
AIM: To explore the clinical features and surgical treatment of aggressive meningiomas (AMs).

MATERIAL and METHODS: Samples from 55 patients with AMs were analyzed, and their clinical characteristics, molecular biological mechanism, and surgical treatment were studied in combination with the literature.

RESULTS: The main clinical and imaging features of AMs included manifestations of local structures invaded by tumors, frequently irregular or flat tumors in shape, more obvious cerebral edema surrounding the tumors, seldom calcification of tumor, more frequent and typical dural tail sign, often absent white or black ring sign, partial or complete occlusion of venous sinus and hyperplasia and destruction of local skull. Simpson I resection was achieved in 31 cases, II in 13, III-IV in 11. No severe complications and death occurred after operation.
\end{abstract}

CONCLUSION: AMs have prominent clinical features. Appropriate surgery can provide a good therapeutic effect.

KEYWORDS: Aggressive meningiomas, Clinical manifestation, Imaging features, Surgical treatment

öz

AMAÇ: Agresif menenjiyomların (AM) klinik özelliklerini ve cerrahi tedavisini ortaya çıkarmak.

YÖNTEM ve GEREÇLER: AM'u olan 55 hasta incelendi ve bunların klinik özellikleri, moleküler biyolojik mekanizması ve cerrahi tedavisi literatür ile kombine olarak çalışıldı.

BULGULAR: AM'ların ana klinik ve görüntüleme özellikleri; lokal yapıların tümör tarafından invaze edilmesi, sıklıkla şekil olarak düzensiz veya düz tümörler olması, tümörlerin çevresinde belirgin serebral ödem olması, nadiren tümör kalsifikasyonu görülmesi, sık ve tipik dural kuyruk boyanması olması, beyaz veya siyah halka bulgusunun genellikle olmaması, venöz sinüsler kısmi veya tam olarak oklüde olması ve lokal olarak kafatasında hiperplazi ve destrüksiyon olmasıdır. Simpson I rezeksiyon 31 olguda, II rezeksiyon 13 olguda, III ve IV rezeksiyon ise 11 olguda sağlanmıştır. Cerrahiden sonra hiç ciddi bir komplikasyon veya ölüm gerçekleşmemiştir.

SONUÇ: AM'ların belirgin klinik özellikleri vardır. Uygun cerrahi yaklaşım ile iyi bir klinik sonuç alınabilir.

ANAHTAR SÖZCÜKLER: Agresif menenjiyom, Klinik prezantasyon, Görüntüleme özellikleri, Cerrahi tedavi

\section{INTRODUCTION}

Invasiveness is one of the biological characteristics of malignant tumors, and mainly means infiltration, destruction and substitution of the surrounding tissues by the tumors. $5 \%$ to $20 \%$ of benign meningiomas recur after total resection, and their invasive growth is considered to be the main cause of recurrence (9). Aggressive meningiomas (AMs) are defined as benign meningiomas growing invasively into the close-by dura mater, venous sinus, brain, skull and others (911). According to our diagnostic criteria of AMs, 55 patients with AMs, accounting for $65.5 \%$ of all meningiomas, were treated surgically at our hospital between January 2009 and December 2009. On the basis of our 55 patients and reports in the literature, we summarized the molecular biological mechanism, clinical features and surgical treatment of AMs.

\section{MATERIAL and METHODS}

The diagnostic criteria of AMs (9-11) were:
1. Meningiomas with typical dural tail sign (DTS), inapparent white or black ring sign, partial or complete occlusion of venous sinus and hyperplasia and/or destruction of local skull shown by $\mathrm{CT}$ and /or MRI;

2. Tumors invading the adjacent dura mater, venous sinus, brain, skull and others found during operation;

3. Specimen of the invaded tissues containing the cells of meningioma found under microscope; and

4. Meningiomas with the typical benign histological structures.

There were 12 males and 43 females in this series, whose ages ranged from 19 to 75 years old with a mean 50.2 years. The courses of diseases were between 1 day and 12 years (mean 3 years). The symptoms and signs of this group are listed in Table I. All patients were performed CT and/or MRI scanning. $\mathrm{CT} / \mathrm{MRI}$ findings in this series are shown in Table II. AMs can be subtyped into five groups based on the different tissues 
Table I: The Symptoms and Signs of 55 Cases of AMs

\begin{tabular}{|c|c|c|c|}
\hline Symptoms & No. of cases & Signs & No. of cases \\
\hline Headache & 38 & Papilledema & 2 \\
\hline Dizziness & 38 & Mild hemiplegia & 10 \\
\hline Nausea and vomiting & 2 & Mild aphasia & 2 \\
\hline Convulsion & 5 & Ataxia & 5 \\
\hline Vision decrease & 7 & Nystagmus & 4 \\
\hline Diplopia & 1 & Scalp mass & 5 \\
\hline
\end{tabular}

Table II: CT/MRI Findings of 55 Patients with AMs

\begin{tabular}{|c|c|}
\hline Tumors & No. of cases \\
\hline $\begin{array}{l}\text { Locations } \\
\text { cerebral convex } \\
\text { cerebellar tentorium } \\
\text { superior sagittal sinus } \\
\text { olfactory groove } \\
\text { cerebellopontine angle } \\
\text { sphenoidal crest } \\
\text { multiple } \\
\text { tuberculum sellae } \\
\text { cerebral falx } \\
\text { middle cranial fossa }\end{array}$ & $\begin{array}{r}13 \\
10 \\
10 \\
5 \\
3 \\
3 \\
3 \\
3 \\
3 \\
2\end{array}$ \\
\hline 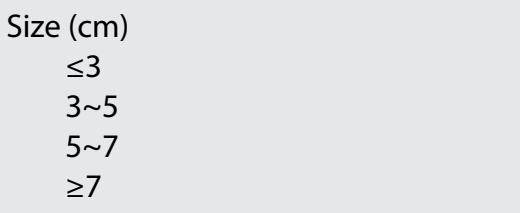 & $\begin{array}{r}4 \\
18 \\
25 \\
8\end{array}$ \\
\hline $\begin{array}{l}\text { Shape (Figure 1A,B) } \\
\text { globular } \\
\text { flat } \\
\text { irregular }\end{array}$ & $\begin{array}{r}39 \\
9 \\
7\end{array}$ \\
\hline $\begin{array}{l}\text { Peritumoral edema (Figure 1C) } \\
\text { apparent } \\
\text { inapparent }\end{array}$ & $\begin{array}{l}38 \\
17\end{array}$ \\
\hline $\begin{array}{l}\text { Black or white ring sign (Figure 1C,D) } \\
\text { apparent } \\
\text { inapparent }\end{array}$ & $\begin{array}{l}37 \\
18\end{array}$ \\
\hline $\begin{array}{l}\text { Dural tail sign (DTS) (Figure 1E,F) } \\
\text { apparent } \\
\text { inapparent }\end{array}$ & $\begin{array}{l}45 \\
10\end{array}$ \\
\hline
\end{tabular}

invaded by tumors, i.e. dura (15 cases) (Figures $1 \mathrm{E}, \mathrm{F}$ ), venous sinus (8 cases) (Figures $1 \mathrm{G}, \mathrm{H}$ ), brain (9 cases) (Figures $1 \mathrm{C}, \mathrm{D}$ ), skull (6 cases, nasal sinuses included) (Figures $1 \mathrm{I}, \mathrm{J}$ ) and mixed (17 cases, two or more than two types of involved tissues) (Figures $1 \mathrm{~K}, \mathrm{~L}$ ) in this series.

All patients were treated microsurgically under general anaesthesia. Pre-operatively, the operative approach was designed according to the locations of the tumors. It was the key to completely expose the tumor and the invaded structures. The removal extent of the invade dura maters and skull must be large enough. Repair or reconstruction of the invaded skull bases was necessary. Management strategies of invaded venous sinus varied with its location, occlusion degree, establishment of collateral circulation and others. Bipolar coagulation, removal, repair or reconstruction of the invaded venous sinus may be performed according to the different circumstances. Repeat coagulation with bipolar can be adopted if only the wall of venous sinus is invaded. Total removal of the involved part is appropraite for severe invasion of the anterior one-third of the superior sagittal sinus, especially if tumor is growing into the sinus. The repair or reconstruction of venous sinus should be carried out after the intra-sinus tumor was removed if the posterior two-thirds of superior sagittal sinus was destroyed badly or if there was tumor intrusion. Simpson III-IV resection of the tumor may be performed if the there is diffuse sinus involvement by the tumor. Sharp separation of tumor from the involved cerebral tissue is performed under the microscope.

\section{RESULTS}

\section{Intra-Operative Findings}

The operative findings included the following single or combined changes;

scalp and skull It might be found that the tumor broke through skull and grew subcutaneously after exiting the scalp. The local skull showed irregular hyperplasia and destruction. Usually, the dissociative bone flap was difficult to take off because the tumor, dura mater and skull had become integrated.

dura mater It presented with the visible incrassation or nodular hyperplasia of the surrounding dura mater the tumor was attached to.

venous sinus The tumor corroded or penetrated through the wall of the venous sinus and grew into the venous sinus.

brain tissue The interface between tumor and brain disappeared, and the local subarachnoid space closed up. The tumor adhered to the cerebral cortex and the blood supply of the tumor developed from the brain. The peritumoral cerebral edema was often obvious.

tumor shape The tumor grew in an irregular, lobulated, or flat shape (Figures 1A, B). 


\section{Surgical Outcomes}

Simpson I resection was achieved in 31 cases, II in 13, III-IV in 11 according to Simpson criteria (8). The total removal rate of tumors was $80 \%$ in this group. Postoperatively, no severe complication occurred except aggravated hemiplegia in five cases and anosmia in one case and there was no death in this series.

\section{Pathological Results}

Benign meningioma was confirmed histologically in all cases (Figure 2). Among these, the pathological sub-types included twenty-two cases of fibrous meningioma, sixteen epithelial, thirteen mixed and two angiomatous and psammomatous respectively.

\section{Follow-up}

Clinical and radiographic follow-up was done in all patients. The duration of follow-up was from 12 to 26 months. All clinical symptoms and signs disappeared and no recurrence of tumor was found during follow-up.

\section{DISCUSSION}

\section{Concept of AMs}

Younis first put forward the concept of AMs in 1995 (11). Afterwards, this concept was accepted by most of neurosurgeons despite some controversy. Malignant and atypical meningiomas have high invasiveness, which were ascribed to AMs by some scholars (1). However, they were excluded from our group as we believe that aggression is
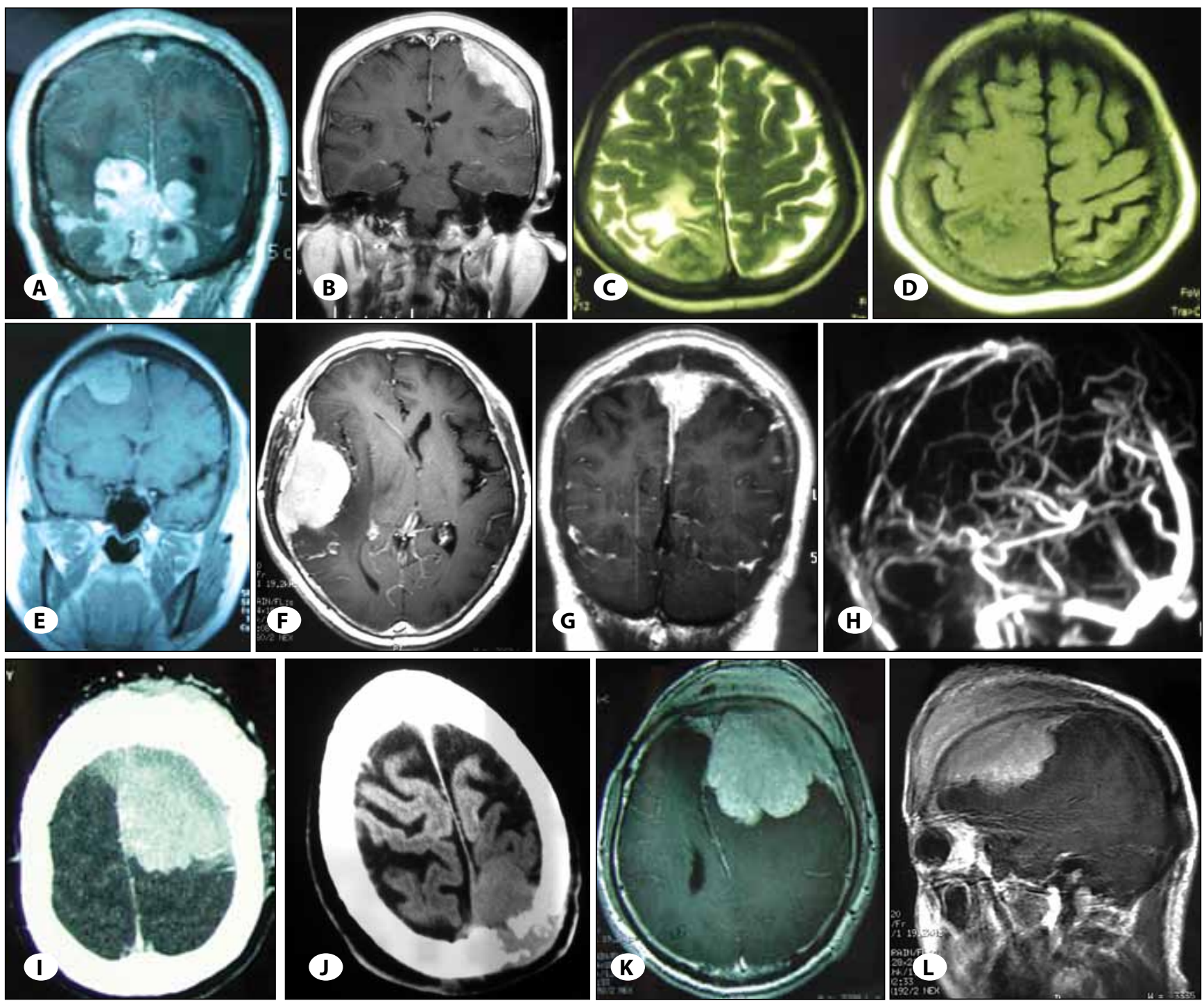

Figure 1: A, B) Contrast enhancement MRI showing an irregular and a flat AM respectively. C, D) MRI showed an AM with cerebral edema and without black or white ring sign. E, F) Contrast enhancement MRI images of AMs with typical DTS. G, H) Contrast enhancement MRI and MRA showed an AM with involved superior sagittal sinus and an occlusion of middle one-third of superior sagittal sinus. I, J) CT images of tumors accompanied by local hyperplasia together with destruction of bone. $\mathbf{K}, \mathbf{L}$ ) Contrast enhancement MRI showed that brain, dura mater, skull and scalp were all invaded by tumor. 


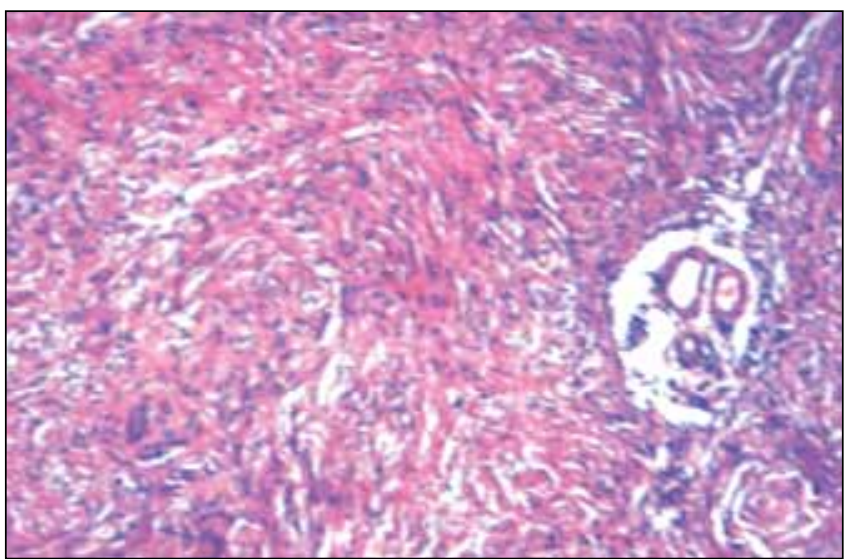

Figure 2: Pathology confirmed the meningioma was benign (H\&E, 20×10).

the inherent biological characteristic of malignant tumors. Though AMs had no significant difference from non-AMs in histocytology, their biological behavior was different and AMs were therefore defined according to their biological behavior. It was easy to make the correct diagnosis and decide on the right surgical procedure in cases with visible invasive manifestations on $\mathrm{CT} / \mathrm{MRI}$ or under naked eye during the operation. However, it was difficult to determine whether the tumors invaded the surrounding tissues or not even under the microscope if the specimen did not contain the interface between tumors and invaded tissues (7).

\section{Molecular Biological Mechanisms of AMs}

It was found that the invasiveness of meningiomas was mainly due to vascular generation of the tumor, degradation of peritumoral extracellular matrices, enhancement of cellular adhesion, and migration of the tumor $(1,4,5,7)$. It is well known that vascular endothelial growth factor (VEGF) can promote the proliferation of vascular endothelia and vascular generation. Both fibroblast growth factor (FGF) and carbonic anhydrase (CA) can also promote vascular growth and express themselves at different levels in meningiomas $(5,7)$ Matrix metalloproteinase (MMP) and tissue inhibitor of metalloproteinase (TIMP) mediate the degradation of peritumoral extracellular matrices. The overexpression of MMP and the unbalanced TIMP level in meningiomas are closely related to invasiveness. Integrins, osteonectins, cadherins and others influence the adhesion of tumoral cells. The expression levels of these adhesive molecules are significantly higher in AMs than those in non-AMs $(1,7)$. The enhancement of adhesion between tumor cells and matrixes is one of the important mechanisms of aggressive growth of meningiomas. In addition, Kitange et al. found that the expression rate of urokinase-type plasminogen activator (uPA) receptor was significantly higher in AMs than that in non-AMs. The expression of the uPA receptor could therefore have a significant correlation with the presence of AMs and uPA could be used as a marker of AMs (4).

\section{Clinical and Imaging Features of AMs}

Compared with non-AMs, AMs have the following clinical and imaging features:

1. They often manifest with the symptoms of the local structures invaded, such as local headache, localized epilepsy, scalp mass and so on, which are mainly due to invasion of the tumor into the dura mater, cerebral cortex, skull and scalp.

2. DTS appears more frequently ( $82 \%$ in this group) at a rate significantly higher than that of meningiomas in general (52\% 72\% in the literature) (3). Generally speaking, DTS is the typical imaging features of AMs (10). The reason is that DTS is composed of tumoral cells, fibrous connective tissue and expanded vessels. The cellular infiltration of tumor is the pathological basis of DTS. However, some do not believe that DTS is a reliable manifestation of AMs considering it is only secondary reactive hyperplasia of vascular tissue in some cases (6). In our opinion, the catenular non-homogeneous enhancement of peritumoral dura mater is the credible imaging manifestation of AMs.

3. The white or black ring-sign is often absent. The interface between tumor and brain disappears and the local subarachnoid space closes up when the tumor has grown invasively into the brain.

4. The tumor grows into the cerebral venous sinus. Partial or complete occlusion of the venous sinus is another typical characteristic of AMs.

5. The tumor is frequently irregular or flat in shape. The inhomogeneous distribution of high proliferative cells in the AMs makes the tumor irregular or flat in shape.

6. The cerebral edema surrounding the tumor is more obvious. Involvement of cerebral cortex veins and venous sinuses by tumor results in the disturbance of local blood circulation. Therefore, the cerebral edema is usually marked.

7. Calcification of tumor seldom happens. About $18 \%$ of meningiomas have calcification. However, AMs with calcification are infrequent because the calcified meningiomas possess lower proliferative capacity and invasiveness (2).

8. The local skull has hyperplasia and destruction. There is consensus on skull destruction being the typical manifestation of AMs. Tumor secretions stimulate the osteoblasts in the adjacent normal skull and give rise to hyperplasia.

\section{Diagnosis of AMs}

Preoperatively, CT and/or MRI are the important diagnostic tool of AMs. The preliminary diagnosis can generally be made according to the obvious DTS, absent white or black ring-sign, occlusion of venous sinus and hyperplasia, and destruction of local skull. The operative findings are as important as the histopathological results to make sure the lesion is an AM.

\section{Surgical Treatment of AMs}

Surgical removal is the first treatment choice of AMs. Correct 
management of the involved tissues is the key to increasing the long-term treatment effect after the tumor is excised completely.

Management of the involved skull and scalp: In principle, the involved cranium should be removed if there is marked invasion. The removal extent should be 0.5 to $1.0 \mathrm{~cm}$ outside of the abnormal bone. In addition, the invaded scalp is also excised at the same time. The bone flap may also be replaced after it is boiled for 30 minutes and the hyperplastic part is evened out. However, marked resorption of the replaced boiled bone flap may happen in the minority of the cases. It is suggested that the artificial repair materials of cranium should be used when the defect of bone is large. The reconstruction of the invaded skull base should be performed after Simpson I resection of tumor. Sometimes, it is difficult to judge the extent and layers of scalp invaded by tumor. It is necessary to decide on the removal degree of the involved scalp with the help of a quick intraoperative pathological examination. Sutures can be placed after resection if a small area of scalp is involved in all layers. Scalp flap transfer or skin-grafting is needed if the area is large.

Management of the involved dura mater: There is no doubt that the involved dura mater should be ablated. Furthermore, the removal extent should be at least $0.5 \mathrm{~cm}$ beyond the abnormal dura mater. It has been proven that there are a lot of tumoral cells in the abnormal dura mater manifesting as DTS and no tumoral cells in the dura mater $0.5 \mathrm{~cm}$ beyond the abnormal dura mater (6). Repeated coagulation of the involved dura mater with bipolar is also an alternative scheme if it cannot be resected. The repair of the dural defect is necessary.

Management of the involved venous sinuses: The involved venous sinuses such as the anterior one-third of the superior sagittal sinus or complete occlusion of venous sinuses can be ligated and removed. Similarly, the removal extent should be over $0.5 \mathrm{~cm}$ beyond the two ends of the involved venous sinuses. The walls of the involved venous sinuses may be coagulated repeatedly with bipolar if they cannot be excised. Repair or reconstruction of the venous sinus is a perfect plan after complete removal of the involved venous sinus and intra-sinusal tumor. However, the procedure is difficult and risky.
Management of the involved brain: The involved brain in an unimportant functional area can be ablated and the involved brain in an important functional area should be isolated and separated from the tumor under the microscope. Avoid damaging the local cerebral cortex and cortical vessels is crucial to prevent neurological deficits after the operation.

\section{REFERENCES}

1. Ceng LC: Development of molecular biological mechanisms of invasive meningiomas. Chinese Journal of Clinical Neurosurgery 12:698-702, 2007

2. Chang CY, Guo SZ, Niu SJ, Liu YG: Clinical characteristics and surgical treatment of calcified meningiomas. Chinese Journal of Neurosurgery 27:610-612,2011

3. Concise Neurosurgery. Liu YG (ed). Jinan: Shandong Scientific and Technological Press, 2010:161-230

4. Kitange G, Tsunoda K, Anda T, Nakamura S, Yasunaga A, Naito $S$, Shibata S: Immunohistochemical expression of Ets1 transcription factor and the urokinase-type plasminogen activator is correlated with the malignant and invasive potential in meningiomas. Cancer 89:2292-2300, 2000

5. Lamszus K, Lengler U, Schmidt NO, Stavrou D, Ergün $S$, Westphal M: Vascular endothelial growth factor, hepatocyte growth factor/scatter factor, basic fibroblast growth factor, and placenta growth factor in human meningiomas and their relation to angiogenesis and malignancy. Neurosurgery 46:938- 948, 2000

6. Li HY, Meng QH, Yao WC, Meng YX: Histological analysis and clinical significance of meningioma dural tail sign. Medical Journal of Qilu 19:215-216, 2004

7. Li Q: Molecular biological research progress of invasiveness of meningiomas. Journal of International Neurology and Neurosurgery 36:181-184, 2009

8. Simpson D: The recurrence of intracranial meningiomas after surgical treatment. J Neurol Neurosurg Psychiatry 20:22-39, 1957

9. Yamasaki F, Yoshioka H, Hama S, Sugiyama K, Arita K, Kurisu K: Recurrence of meningiomas. Cancer 89:1102-1110, 2000

10. Yang K, Takashi K, He LS, Cai X, Dai LS: Imaging characteristics of invasive meningiomas and surgical strategy. Chinese Journal of Clinical Neurosurgery 12:708-711, 2007

11. Younis GA, Sawaya BA, DeMonte F, Hess KR, Albrecht S, Bruner JM: Aggressive meningeal tumors: Review of a series. J Neurosurg 82:17-27, 1995 